\title{
PENGARUH JENJANG PENDIDIKAN DAN PELATIHAN AKUNTANSI TERHADAP PENGGUNAAN INFORMASI AKUNTANSI PADA USAHA UMKM MITRA BINAAN BANK SUMUT MEDAN
}

\author{
Dra. Listiorini, M.Si. ${ }^{1)}$, Desi Ika, SE., M.Si. ${ }^{2)}$ \\ ${ }^{1}$ Prodi Akuntansi, FEB UNHAR Medan \\ (rini66@yahoo.com) \\ ${ }^{2}$ Prodi Akuntansi, FEB UNHAR Medan \\ (desiika2@gmail.com)
}

\begin{abstract}
ABSTRAK
Penelitian ini dilakukan untuk mengetahui pengaruh jenjang pendidikan pemilik atau manajer dan pelatihan akuntansi terhadap penggunaan informasi akuntansi pada usaha mikro, kecil dan menengah mitra binaan Bank Sumut Cabang Medan. Metode penelitian yang digunakan dalam penelitian ini adalah regresi linier berganda. Analisis didasarkan pada data dari 84 responden penelitian yang pengumpulan datanya dilakukan dengan mengumpulkan data primer berupa penyebaran kuesioner, dimana teknik pengambilan sampel dilakukan dengan metode sample random sampling. Adapun hasil penelitian yang diperoleh adalah secara simultan, keseluruhan variabel penelitian yaitu jenjang pendidikan pemilik dan pelatihan akuntansi berpengaruh terhadap penggunaan informasi akuntansi pada usaha mikro, kecil dan menengah mitra binaan Bank Sumut Cabang Medan. Sedangkan secara parsial, jenjang pendidikan tidak berpengaruh signifikan terhadap penggunaan informasi akuntansi pada Usaha Mikro Kecil dan Menengah. Sementara itu untuk variabel kepelatihan akuntansi berpengaruh signifikan terhadap penggunaan informasi akuntansi pada Usaha Mikro Kecil dan Menengah.
\end{abstract}

Kata kunci: Jenjang Pendidikan, Pelatihan Akuntansi, dan Penggunaan Informasi Akuntansi

\section{A. PENDAHULUAN}

Untuk meningkatkan kesejahteraan masyarakat, salah satu cara dengan melakukan wirausaha. Dengan wirausaha membuat masyarakat menjadi mandiri dan membuka peluang untuk menarik keuntungan. Dalam perekonomian Indonesia, sektor usaha kecil dan menengah memegang peranan penting, terutama bila dikaitkan dengan jumlah tenaga kerja yang mampu diserap oleh usaha kecil dan menengah tersebut. Kondisi perekonomian yang tidak stabil di Indonesia membuat usaha mikro kecil dan menengah (UMKM) merupakan jalan keluar yang baik untuk membantu mengurangi tingkat pengangguran dan penciptaan lapangan pekerjaan. Usaha mikro kecil dan menengah (UMKM) merupakan salah satu pilihan masyarakat untuk dijadikan sebagai mata pencaharian sehari-hari. UMKM merupakan potensi yang sangat strategis bagi perekonomian nasional. Hal ini disebabkan oleh menyebarnya UMKM sampai ke pelosok pedesaan serta jumlahnya yang banyak (Salamah, 2010). 
Meskipun UMKM memiliki potensi untuk berkembang, namun mengembangkan usaha bukanlah hal yang mudah. Suryo (2008) menyatakan bahwa selain modal dan akses pasar yang dapat menyulitkan UMKM untuk berkembang, banyak UMKM tak mampu menjadi besar karena tidak memiliki pembukuan yang sistematis, akibatnya tidak ada pemilihan tegas antara uang pribadi dan uang perusahaan. Informasi akuntansi bisa dikatakan berpengaruh dan berperan terhadap kinerja usaha, karena dari informasi akuntansi bisa dijadikan alat dalam pengambilan keputusan dan sangat bermanfaat untuk mengetahui bagaimana struktur modal dan berapa keuntungan yang diperoleh perusahaan tersebut dalam satu periode tertentu (Pacter, 2007 dalam Handayani, 2011). Pengelolaan keuangan yang baik dalam menjalankan usaha diperlukan pengetahuan dan keterampilan akuntansi secara baik pula oleh pelaku usaha. Dalam hal ini tingkat pendidikan pemilik dan pengalaman usaha sangat dibutuhkan dalam penggunaan informasi akuntansi.

Sistem informasi akuntansi adalah suatu bagan yang menggumpulkan, menggolongkan, mengolah, menganalisa, dan komunikasikan informasi keuangan untuk pengambilan keputusan kepada pihak luar perusahaan (pemerintah, otoritas pajak, dan calon pemegang saham) dan pihak dalam perusahaan dalam hal ini pihak pemegang saham (Baridwan, 2004). Sistem akuntansi sangat diperlukan bagi semua bidang usaha baik pengusaha kecil, menengah maupun besar. Sistem ini akan dapat memudahkan kerjasama dalam hal pendanaan kepada pihak ketiga, dan salah satu syarat peminjaman dana harus melampirkan laporan keuangan tahunan dari si peminjam tersebut.

Peraturan Bank Indonesia No.14/22/PBI/2012 pasal 5 mengenai pemberian kredit atau pembiayaan oleh bank umum dalam rangka pengembangan UMKM dalam pemberian kredit atau pembiayaan UMKM, yang menjadi salah satu persyaratan adalah informasi akuntansi yang berupa laporan keuangan yang disediakan UMKM. Namum pentingnya penerapan ilmu akuntansi dalam mengelola usaha kecil menengah dinilai masih kurang dipahami oleh para pengusaha namun masih banyak pengusaha kecil yang belum melakukan pencatatan laporan keuangan usahanya dengan baik. Bahkan ada yang tidak melakukan pencatatan, oleh karena minimnya pengetahuan pengusaha tersebut tentang sistem pencatatan akuntansi. Mereka hanya mengerjakan sebatas pencatatan pendapatan dan pengeluaran saja. Akibatnya laba bersih perusahaan sulit untuk diketahui sehingga hal tersebut menjadi kendala bagi UMKM dalam mengajukan kredit. Hanya karena tidak adanya laporan keuangan yang baik dan berkualitas. Laporan keuangan akan dapat memudahkan kerjasama dalam hal pendanaan kepada pihak ketiga. Laporan keuangan bermanfaat untuk penilaian kinerja dari suatu usaha diantaranya untuk mengetahui berapa perolehan laba suatu perusahaan yang bermanfaat untuk menjaga kesinambungan usahanya. Laporan keuangan merupakan hasil akhir dari proses akuntansi yang dapat digunakan oleh berbagai pihak yang berkepentingan dalam mengambil suatu keputusan.

Dengan akuntansi yang memadai maka pengusaha UMKM dapat memenuhi persyaratan dalam pengajuan kredit berupa laporan keuangan, mengevaluasi kinerja, mengetahui posisi keuangan dan manfaat lainnya. Menurut penelitian yang dilakukan oleh Grace (2010) menunjukkan bahwa lama usaha dan 
pendidikan formal berpengaruh terhadap penyajian dan penggunaan informasi akuntansi. Sedangkan penelitian yang dilakukan oleh Wahyudi (2009) menunjukkan bahwa jenjang pendidikan pemilik / manajer dan skala usaha berpengaruh terhadap penggunaan informasi akuntansi pada UMKM dengan sampel UMKM yang berada di Yogyakarta.

Berdasarkan latar belakang tersebut, maka peneliti ingin penelitian ini dilakukan untuk mengetahui bagaimana pengaruh jenjang pendidikan dan kepelatihan akuntansi terhadap penggunaan informasi akuntansi pada usaha mikro kecil dan menengah (UMKM) Mitra Binaan Bank Sumut Cabang Medan”.

\section{Kondisi dan Potensi Usaha Mikro Kecil dan Menengah (UMKM)}

Salah satu cara untuk mengatasi permasalahan ekonomi di Indonesia adalah UMKM. UMKM sangat membantu mengurangi pengangguran di Indonesia, karena UMKM menciptakan lapangan pekerjaan sendiri dengan cara membuka usaha. Selain itu UMKM juga sebagai penyumbang tenaga kerja yang cukup banyak sehingga dapat meminimalisirkan pengangguran di Indonesia. UMKM merupakan salah satu cara yang tepat untuk meningkatkan pertumbuhan ekonomi nasional karena UMKM biasanya memanfaatkan segala penunjangnya yang bersifat lokal, seperti sumber daya alam dan manusia lokal. Sehingga meminimalisirkan biaya pengimporan dan memaksimalkan pengeksporan.

Kendala-kendala UMKM di Indonesia adalah sebagai berikut:

a. Teknologi Indonesia belum maju untuk pasaran global.

b. Rendahnya keahlian dan kemampuan tenaga kerja.

c. Kurangnya pengetahuan strategi bisnis global.

d. Kurangnya pengetahuan tentang pasar.

e. Terbatasnya dalam mengakses modal.

Daya saing pasar global memang ketat. Dilihat dari kemampuan pengeksporan Indonesia masih kalah dengan negara berkembang lain seperti India. Indonesia belum menguasai strategi pemasaran global sehingga perlu adanya perhatian dari pemerintah untuk melakukan pelatihan kepada pelaku UMKM dalam rangka menambah pengetahuan tentang daya saing pasar global dan strategi pemasaran

\section{Pengertian Akuntansi}

Secara umum, akuntansi (accounting) dapat dipahami sebagai suatu proses kegiatan mengolah data keuangan (input) agar menghasilkan informasi keuangan (output) yang bermanfaat bagi pihak-pihak yang berkepentingan dengan perusahaan atau organisasi ekonomi bersangkutan. American Accounting Association dalam Belkaoui (2011) mendefinisikan akuntansi sebagai proses mengidentifikasikan, mengukur, dan melaporkan informasi ekonomi, untuk memungkinkan adanya penilaian dan keputusan yang jelas dan tegas bagi mereka yang menggunakan informasi tersebut.

Menurut A Statement Of Basic Accounting Theory (ASOBAT) akuntansi adalah proses mengidentifikasikan, mengukur dan menyampaikan informasi ekonomi bagi para penggunanya dalam mempertimbangkan berbagai alternatif yang ada dan membuat kesimpulan. Kedua defenisi ini mengandung dua pengertian yakni: Kegiatan akuntansi meliputi proses identifikasi, mengukur, dan 
menyampaikan informasi ekonomi dan informasi akuntansi yang dibuat dapat membantu pemilik dalam mengambil keputusan.

\section{Sistem Informasi Akuntansi}

Belkaoui (2011) mendefinisikan informasi akuntansi sebagai informasi kuantitatif tentang entitas ekonomi yang bermanfaat untuk pengambilan keputusan ekonomi dalam menentukan pilihan-pilihan di antara alternatifalternatif tindakan. Haswell dan Holmes dalam Astuti (2007) menyatakan bahwa kekurangan informasi akuntansi dalam manajemen perusahaan dapat membahayakan perusahaan kecil. Kondisi keuangan yang memburuk dan kekurangan catatan akuntansi akan membatasi akses untuk memperoleh informasi yang diperlukan, sehingga akan menyebabkan kegagalan perusahaan.

Holmes dan Nicholls dalam Astuti (2007) mengklasifikasikan informasi akuntansi dalam tiga jenis yang berbeda-beda menurut manfaatnya bagi para pemakai, yaitu:

1. Informasi akuntansi statutori (Statutory accounting information) merupakan informasi yang harus disiapkan sesuai dengan peraturan yang ada.

2. Informasi anggaran (Budgetary Information) merupakan informasi akuntansi yang disajikan dalam bentuk anggaran yang berguna bagi pihak internal dalam perencanaan, penilaian, dan pengambilan keputusan.

3. Informasi tambahan merupakan informasi akuntansi lain yang disiapkan perusahaan guna meningkatkan efektivitas pengambilan keputusan, seperti laporan gaji karyawan, laporan jumlah produksi dan laporan biaya produksi.

Mulyadi (2001) mendefinisikan sistem akuntansi sebagai berikut: "Sistem akuntansi adalah organisasi formulir, catatan, dan laporan yang dikoordinasi sedemikian rupa untuk menyediakan informasi keuangan yang dibutuhkan oleh manajemen guna memudahkan pengelolaan perusahaan". Kesimpulannya sistem akuntansi merupakan organisasi yang terdiri dari formulir, catatan dan laporan yang dikoordinasikan untuk menyediakan informasi keuangan yang dibutuhkan oleh pengambil keputusan dalam hal ini manajemen.

\section{Laporan Keuangan}

Baridwan (2004), menyatakan bahwa laporan keuangan adalah merupakan ringkasan dari suatu proses pencatatan, merupakan suatu ringkasan, dan transaksitransaksi keuangan yang terjadi selama satu tahun buku yang bersangkutan. Kemudian, pengertian di dalam standar akuntansi keuangan, laporan keuangan adalah merupakan bagian dari proses pelaporan keuangan dan laporan keuangan lengkap biasanya meliputi neraca, laporan laba rugi, laporan perubahan posisi keuangan (yang dapat disajikan dalam berbagai cara, seperti sebagai laporan arus kas), catatan, laporan keuangan lain, dan materi penjelasan yang bagian integral dari laporan keuangan.

Pada umumnya, laporan keuangan itu terdiri dari neraca, laporan laba-rugi, serta laporan perubahan modal, tetapi dalam praktik keseharian sering pula diikutsertakan kelompok lain yang sifatnya membantu memperoleh penjelasan, seperti laporan sumber dan penggunaan kas atau arus kas, laporan biaya produksi, dan lain-lain. Oleh karena itu, laporan keuangan dapat dipakai sebagai alat berkomunikasi dengan pihak-pihak berkepentingan dengan data keuangan perusahaan, dan karena itulah sering juga disebut sebagai language of business. 
Jadi, idealnya sebuah catatan laporan keuangan harus mampu mencerminkan dan memberikan gambaran yang akurat tentang kondisi keuangan kinerja suatu perusahaan.

\section{Jenjang Pendidikan}

Jenjang pendidikan adalah tahapan pendidikan berdasarkan tingkat perkembangan peserta didik, tujuan yang akan dicapai dan kemampuan yang dikembangkan. Jenjang pendidikan terdiri atas pendidikan formal, non formal dan informal yang dapat saling melengkapi. Pendidikan tersebut diselenggarakan dengan sistem terbuka melalui tatap muka atau dan melalui jarak jauh. Samuj (2007) menyatakan bahwa tingkatan pendidikan formal pemilik atau manajer usaha kecil dan menengah sangat mempengaruhi penggunaan informasi akuntansi keuangan dan manajemen. Tingkat pendidikan formal yang rendah (SD sampai dengan SMP), maka pemilik atau manajer akan rendah dalam penggunaan informasi akuntansi dibandingkan dengan tingkat pendidikan formal yang tinggi (perguruan tinggi). Pendidikan formal yang dimaksud adalah pendidikan yang diperoleh di bangku sekolah formal antara lain Sekolah Dasar (SD), Sekolah Menengah Pertama (SMP), Sekolah Menengah Atas (SMA) dan yang sederajat, Diploma III (D-III), Sarjana (S-1) dan Pascasarjana (S-2 dan S-3).

\section{Pelatihan}

Pelatihan menurut Dessler dalam Wahyudi (2009) adalah proses mengajarkan karyawan baru atau yang ada sekarang, keterampilan dasar yang mereka butuhkan untuk menjalankan pekerjaan mereka. Pelatihan merupakan salah satu usaha dalam meningkatkan mutu sumber daya manusia dalam dunia kerja. Karyawan, baik yang baru ataupun yang sudah bekerja perlu mengikuti pelatihan karena adanya tuntutan pekerjaan yang dapat berubah akibat perubahan lingkungan kerja, strategi, dan lain sebagainya. Dari defenisi di atas dapat diambil kesimpulan tujuan pelatihan adalah agar para pegawai dapat menguasai pengetahuan, keahlian dan perilaku yang ditekankan dalam program-program pelatihan dan untuk diterapkan dalam aktivitas sehari-hari para karyawan. Pelatihan juga mempunyai pengaruh yang besar bagi pengembangan perusahaan.

\section{Kerangka Konseptual}

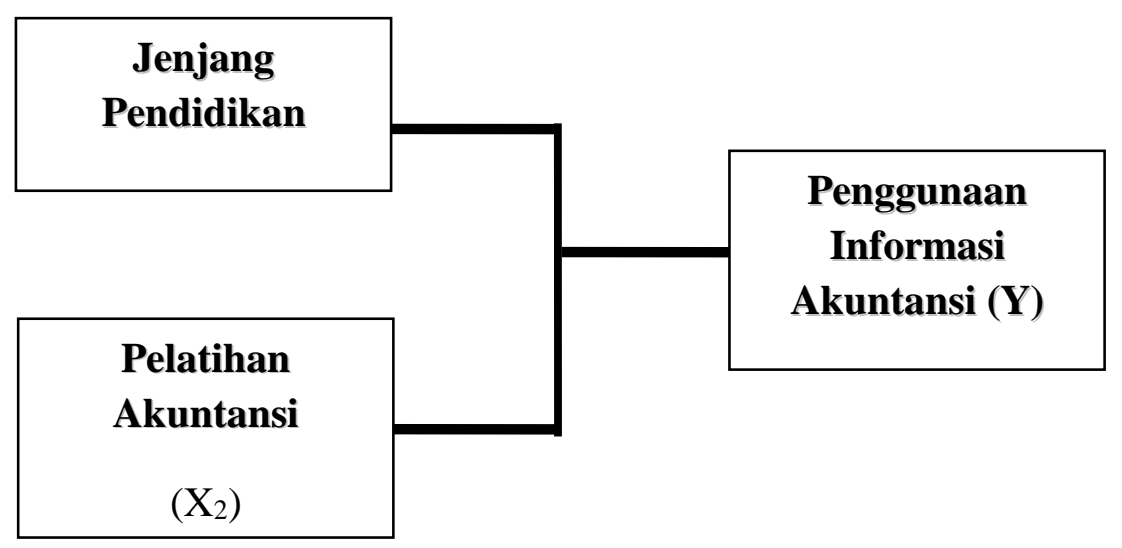

Gambar 1 Kerangka Konseptual 
Hipotesis yang dapat diajukan sesuai dengan kerangka pemikiran di atas adalah sebagai berikut:

$\mathrm{H}_{1}$ : Jenjang pendidikan pemilik atau manajer perusahaan berpengaruh terhadap penggunaan informasi akuntansi pada usaha mikro, kecil dan menengah mitra binaan Bank Sumut Cabang Medan.

$\mathrm{H}_{2}$ : Pelatihan akuntansi berpengaruh terhadap penggunaan informasi akuntansi pada usaha mikro, kecil dan menengah mitra binaan Bank Sumut Cabang Medan.

$\mathrm{H}_{3}$ : Jenjang pendidikan pemilik atau manajer, pelatihan akuntansi, secara simultan berpengaruh terhadap penggunaan informasi akuntansi pada usaha mikro, kecil dan menengah mitra binaan Bank Sumut Cabang Medan.

\section{B. METODE PENELITIAN} Jenis dan Lokasi Penelitian

Jenis penelitian yang digunakan dalam penelitian ini adalah explanatory reseach (penelitian penjelasan). Penelitian penjelasan merupakan penelitian yang menyoroti hubungan antara variabel-variabel penelitian dan menguji hipotesis yang telah dirumuskan sebelumnya (Singarimbun \& Effendi, 1995). Oleh karenanya penelitian ini juga dinamakan penelitian pengujian hipotesis / testing research.

Tujuan penelitian ini untuk menguji hipotesis penelitian yang berkaitan dengan variabel yang diteliti. Hasil pengujian data digunakan sebagai dasar untuk menarik kesimpulan penelitian, mendukung atau menolak hipotesis yang dikembangkan dari telaah teoritis. Penelitian ini akan mengindentifikasi bagaimana variabel independen mempengaruhi variabel dependen. Penelitian ini berlokasi di PT Bank SUMUT Cabang Medan Jalan Imam Bonjol No 18 Medan.

\section{Pengambilan Sampel}

Populasi dalam penelitian ini adalah seluruh pemilik dari UMKM binaan PT Bank Sumut Cabang Medan. Sampel yang digunakan dalam penelitian ini menggunakan teknik sample random sampling. Menurut Sugiyono (2008) dinyatakan sampel sederhana karena pengambilan sampel anggota populasi dilakukan secara acak tanpa memperhatikan strata yang ada dalam populasi itu. Dengan demikian setiap unit sampling sebagai unsur populasi memperoleh peluang yang sama untuk menjadi sampel atau untuk mewakili populasi. Ukuran sampel dihitung dengan menggunakan rumus Slovin yaitu :

$$
n=\frac{N}{1+N(e)^{2}}
$$

$$
\begin{aligned}
& \text { di mana: } \begin{aligned}
& \mathrm{n}=\text { ukuran sampel } \\
& \mathrm{N}=\text { ukuran populasi } \\
& \mathrm{e} \quad \begin{array}{l}
\text { kelonggaran ketidaktelitian karena kesalahan pengambilan } \\
\text { sampel yang dapat ditolerir. }
\end{array} \\
& n=\frac{515}{1+515(0,10)^{2}}
\end{aligned}
\end{aligned}
$$




$$
\begin{aligned}
n=\frac{515}{1+6,15} & \\
n & =83,73 \text { dibulatkan menjadi } 84
\end{aligned}
$$

Sehingga sampel yang digunakan dalam penelitian ini adalah 84 UMKM.

\section{Definisi Operasional Variabel}

Variabel bebas (Independent Variabel) yang digunakan dalam penelitian ini yaitu pendidikan pemilik, pelatihan akuntansi. Variabel terikat (dependent variabel) yang merupakan perhatian utama adalah penggunaan informasi akuntansi.

Instrumen dan alat ukur yang digunakan untuk mengukur variabel-variabel sebagai berikut :

1. Jenjang Pendidikan (X1).

Jenjang pendidikan akan diukur berdasarkan pendidikan formal yang pernah diikuti. Pendidikan formal yang dimaksud adalah pendidikan yang diperoleh di bangku sekolah formal antara lain Sekolah Dasar (SD), Sekolah Menengah Pertama (SMP), Sekolah Menengah Atas (SMA) dan yang sederajat, Program Diploma III (D-III), Sarjana (S-1) dan Pasca sarjana (S-2 dan S-3)). Pengukuran jenjang pendidikan pemilik menggunakan skala nominal dengan pemberian kode 1 untuk SD, kode 2 untuk SMP, kode 3 untuk SMA, kode 4 untuk D-III s/d S-1 dan kode 5 untuk pasca sarjana (S-2 s/d S-3).

2. Pelatihan Akuntansi (X2)

Pelatihan Akuntansi yang dimaksud adalah pelatihan akuntansi yang diselenggarakan oleh suatu lembaga pendidikan luar sekolah maupun lembaga pendidikan tinggi, balai pelatihan departemen atau dinas tertentu. Latihan yang dilakukan di luar pekerjaan dimaksudkan untuk meningkatkan keterampilan. Bila latihan formal seperti itu betul-betul dikaitkan dengan penggunaannya dalam pekerjaan sehari-hari maka dapat disimpulkan bahwa tingkat kinerja akan meningkat. Pengukuran indikator menggunakan skala likert lima poin, dimana nilai 1 untuk mengambarkan sangat tidak setuju, poin 2 untuk tidak setuju, poin 3 cukup setuju, poin 4 setuju dan poin 5 sangat setuju dengan pelatihan akuntansi pada UMKM. (Grace, 2003) menggunakan skala interval.

3. Penggunaan informasi akuntansi (Y)

Penggunaan informasi akuntansi merupakan variabel dependen (terikat). Penggunaan informasi akuntansi merupakan informasi yang diberikan kepada perusahaan yang diwajibkan oleh undang-undang atau peraturan lainnya yang berlaku di Indonesia untuk disediakan oleh setiap perusahaan (Handayani, 2011). Pengukuran setiap dimensi variabel informasi akuntansi dilakukan dengan skala likert lima poin yaitu nilai 1 untuk mengambarkan sangat tidak setuju, poin 2 untuk tidak setuju, poin 3 cukup setuju, poin 4 setuju dan poin 5 sangat setuju dengan penggunaan informasi akuntansi pada UMKM menggunakan skala interval (Grace, 2003).

\section{Teknik Analisa Data}


Pengujian validitas dan reliabilitas dilakukan terlebih dahulu untuk mengetahui sejauh mana alat ukur yang telah ditentukan mengukur apa yang sesungguhnya hendak diukur dan untuk melihat sejauh mana bisa dipercaya untuk digunakan sebagai alat pengukur. Kemudian uji asumsi klasik dilakukan untuk mengetahui bahwa model terbebas dari masalah normalitas data dan heteroskedastisitas. Teknik analisis data yang digunakan ialah teknik analisis regresi linear berganda.

\section{HASIL PENELITIAN}

Dari 84 eksemplar kuesioner yang disebarkan ternyata hanya sekitar 78 eksemplar yang kembali dan dapat diolah. Dari kuesioner yang dapat diolah tersebut memperlihatkan bahwa mayoritas responden berpendidikan setingkat SMA yaitu sebanyak 57 orang atau 73,08 \% dan sisanya sebanyak 17 orang atau $21,79 \%$ berpendidikan setingkat D-III s/d S-1 dan 4 orang berpendidikan setingkat SMP. Berdasarkan kuesioner yang disebar tidak ada responden yang berpendidikan setingkat SD dan pascasarjana (S-2 s/d S-3). Untuk lebih jelasnya diperlihatkan dalam Tabel 1 berikut ini :

\section{Tabel 1}

\section{Demografi Responden Berdasarkan Jenjang Pendidikan}

\begin{tabular}{|l|l|l|}
\hline Jenjang Pendidikan & Jumlah & $\%$ \\
\hline SD & 0 & $0,00 \%$ \\
\hline SMP & 4 & $5,13 \%$ \\
\hline SMA & 57 & $73,08 \%$ \\
\hline D-III s/d S-1 & 17 & $21,79 \%$ \\
\hline S-2 s/d S3 & 0 & $0,00 \%$ \\
\hline Total & $\mathbf{7 8}$ & $\mathbf{1 0 0 , 0 0 \%}$ \\
\hline
\end{tabular}

Sumber : data diolah, 2018

\section{Uji Validitas dan Reliabilitas}

Uji validitas digunakan untuk mengetahui ketepatan/kehandalan dalam butir pertanyaan dalam mendefinisikan suatu variabel. Dalam uji penelitian ini, uji validitas item-item pernyataan dalam kuesioner dilakukan dengan mengkorelasikan skor jawaban responden dari setiap pertanyaan. Dikatakan valid jika nilai $r$ hitung yang merupakan nilai dari Corrected item-Total Correlation > dari $r$ tabel. Untuk menentukan butir-butir pertanyaan variabel reliabel atau tidak reliabel, digunakan perbandingan antara cronbach's alpha dengan alpha yang ditentukan sebelumnya yaitu 0,60. Jika nilai cronbach's alpha $>0,60$ dikatakan reliabel dan jika nilai cronbach's alpha $<0,60$ dikatakan tidak reliabel (Sunyoto, 2012). 
Tabel 2

Hasil Uji Validitas Variabel Pelatihan

\begin{tabular}{|l|l|l|c|}
\hline \multicolumn{1}{|c|}{$\begin{array}{c}\text { BUTIR } \\
\text { PERTANYAAN }\end{array}$} & R HITUNG & R TABEL & VALID \\
\hline Pelatihan1 & 0,303 & 0,227 & VALID \\
\hline Pelatihan 2 & 0,72 & 0,227 & VALID \\
\hline Pelatihan 3 & 0,601 & 0,227 & VALID \\
\hline Pelatihan 4 & 0,721 & 0,227 & VALID \\
\hline
\end{tabular}

Tabel 3

Hasil Uji Validitas Variabel Penggunaan Informasi Akuntansi

\begin{tabular}{|l|l|l|l|}
\hline $\begin{array}{l}\text { BUTIR } \\
\text { PERTANYAAN }\end{array}$ & R HITUNG & R TABEL & VALID \\
\hline PIA 1 & 0,806 & 0,227 & VALID \\
\hline PIA 2 & 0,703 & 0,227 & VALID \\
\hline PIA 3 & 0,608 & 0,227 & VALID \\
\hline PIA 4 & 0,501 & 0,227 & VALID \\
\hline PIA 5 & 0,586 & 0,227 & VALID \\
\hline PIA 6 & 0,533 & 0,227 & VALID \\
\hline PIA 7 & 0,457 & 0,227 & VALID \\
\hline PIA 8 & 0,598 & 0,227 & VALID \\
\hline PIA 9 & 0,464 & 0,227 & VALID \\
\hline PIA 10 & 0,342 & 0,227 & VALID \\
\hline PIA 11 & 0,584 & 0,227 & VALID \\
\hline PIA 12 & 0,636 & 0,227 & VALID \\
\hline PIA 13 & 0,584 & 0,227 & VALID \\
\hline
\end{tabular}

Sumber : data diolah, 2018

Berdasarkan tabel tersebut di atas didapatkan bahwa nilai $r$ hitung dari masing-masing variabel lebih besar dari nilai $r$ tabelnya, maka pertanyaan yang disajikan adalah valid karena semua skor yang diperoleh berada di atas taraf signifikan yaitu 0,227 .

Kemudian untuk uji reliabilitas dari hasil Cronbach's Alpha yaitu sebesar 0,775 untuk variabel kepelatihan akuntansi serta hasil Cronbach's Alpha dari variabel Penggunaan informasi akuntansi sebesar 0,875 maka penelitian dianggap 
reliabel. Hal ini dikarenakan Cronbach's Alpha dari variabel tersebut > r kritis 0.60 .

Tabel 4

Reliability Statistics

\begin{tabular}{|l|c|c|l|}
\hline \multicolumn{1}{|c|}{ Variabel } & $\begin{array}{c}\text { Jumlah Item } \\
\text { Pertanyaan }\end{array}$ & Cronbach's Alpha & Keterangan \\
\hline $\begin{array}{l}\text { Penggunaan } \\
\text { Informasi } \\
\text { Akuntansi }\end{array}$ & 13 & 0,875 & \\
\hline
\end{tabular}

Sumber : data diolah, 2018

Tabel 5

Reliability Statistics

\begin{tabular}{|l|l|l|l|}
\hline \multicolumn{1}{|c|}{ Variabel } & \multicolumn{1}{|c|}{$\begin{array}{c}\text { Jumlah Item } \\
\text { Pertanyaan }\end{array}$} & Cronbach's Alpha & Keterangan \\
\hline $\begin{array}{l}\text { Pelatihan } \\
\text { Akuntansi }\end{array}$ & 4 & 0,775 & Reliabel \\
\hline
\end{tabular}

Sumber : data diolah, 2018

\section{Pengujian Normalitas}

Uji normalitas bertujuan untuk menguji apakah model regresi pada variabel terikat dan variabel bebas mempunyai distribusi normal atau tidak. Untuk menguji apakah data penelitian ini terdistribusi normal atau tidak dapat dideteksi dengan cara analisis statistik (uji One Sample Kolmogorov Smirnov). Adapun hasil pengujian terdapat pada Tabel 6 berikut :

Tabel 6

One-Sample Kolmogorov-Smirnov Test

\begin{tabular}{|ll|l|}
\hline N & & Unstandardized Residual \\
Normal Parameters ${ }^{\mathrm{a}, \mathrm{b}}$ & Mean & 78 \\
& Std. Deviation &, 43149076 \\
Most Extreme Differences & Absolute &, 118 \\
& Positive &, 046 \\
& Negative &,- 118 \\
Test Statistic & &, 118 \\
Asymp. Sig. (2-tailed) & &, $174^{\mathrm{c}}$ \\
\hline
\end{tabular}

Sumber : data diolah, 2018

\section{Uji Multikolinearitas}


Pengujian multikolinearitas dilakukan untuk melihat apakah pada model regresi ditemukan ada tidaknya korelasi antar variabel bebas. Menurut Ghozali (2005: 93), pada umumnya jika VIF > 10, maka variabel tersebut mempunyai persoalan multikolinearitas dengan variabel bebas lainnya.

Tabel 7

Uji Multikolinieritas

\begin{tabular}{|ll|l|l|}
\hline \multirow{2}{*}{ Model } & \multicolumn{2}{|l|}{ Collinearity Statistics } \\
\cline { 3 - 4 } & Tolerance & VIF \\
\hline 1 & $\begin{array}{l}\text { Pendidikan } \\
\text { Kepelatihan }\end{array}$ & .922 & 1,084 \\
\cline { 3 - 4 } & Kepl & 1.009 \\
\hline
\end{tabular}

Sumber : data diolah, 2018

Dari tabel di atas, terlihat bahwa variabel independen jenjang pendidikan dan kepelatihan mempunyai angka Variance Inflation Factor (VIF) di bawah angka 10, dan nilai Tolerance lebih dari 0,10 yang berarti tidak ada korelasi antar variabel independen yang nilainya lebih dari $95 \%$.

\section{Uji Heteroskedastisitas}

Menurut Ghozali (2005 : 107) model regresi yang baik adalah model yang homoskesdatisitas atau tidak terjadi heteroskedastitas. Pada penelitian ini hasil pengolahan data terdapat pada gambar berikut :

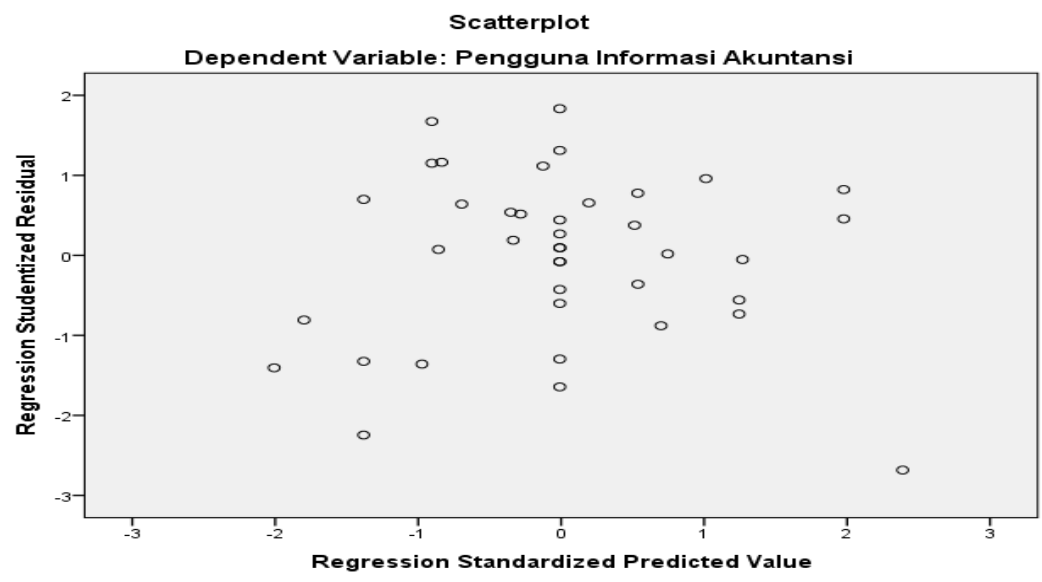

\section{Gambar 4: Uji Heteroskedastisitas}

Sumber : data diolah, 2018

Berdasarkan gambar tersebut bahwa residual memencar di atas (vertikal) dan di bawah sumbu nol secara acak. Dengan demikian dapat disimpulkan model terbebas dari adanya problem heteroskedastisitas, sehingga model regresi layak digunakan.

\section{Uji Hipotesis}

Hipotesis dalam penelitian ini adalah ada pengaruh jenjang pendidikan pemilik, pelatihan akuntansi, terhadap penggunaan informasi akuntansi pada usaha mikro, kecil dan menengah Mitra Binaan Bank Sumut Cabang Medan 
dapat diterima. Nilai Adjusted $R$ Square yang diperoleh dari hasil pengolahan data dapat dilihat pada Tabel di bawah ini :

Tabel 8

Model Summary

\begin{tabular}{|l|l|l|l|l|l|}
\hline Model & $\mathrm{R}$ & R Square & $\begin{array}{l}\text { Adjusted R } \\
\text { Square }\end{array}$ & $\begin{array}{l}\text { Std. Error of } \\
\text { the Estimate }\end{array}$ & $\begin{array}{l}\text { Durbin- } \\
\text { Watson }\end{array}$ \\
\hline 1 &, $433^{\mathrm{a}}$ &, 188 &, 144 &, 51458 & 1,578 \\
\hline
\end{tabular}

a. Predictors: (Constant), Kepelatihan, Pendidikan

b. Dependent Variable: Pengguna Informasi Akuntansi

Sumber : data diolah, 2018

Nilai $R$ Square pada Tabel 8 di atas sebesar 0,188 . Hal ini menunjukkan bahwa 18,8 \% variabel Penggunaan Informasi Akuntansi dapat dijelaskan oleh variabel independen yang ada yaitu pendidikan, kepelatihan. Sisanya sebesar $81,2 \%$ dipengaruhi oleh variabel lain yang tidak dijelaskan oleh model penelitian ini. Untuk melihat tingkat kepercayaan hasil uji hipotesis, selanjutnya dilakukan uji signifikan. Uji signifikan dibedakan atas uji signifikan simultan (uji F) dan uji signifikan parsial (uji t) dengan taraf signifikan $\alpha=5 \%$.

\section{Uji Signifikan Simultan (Uji F)}

Secara simultan variabel Jenjang pendidikan pemilik, pelatihan akuntansi, terhadap penggunaan informasi akuntansi pada usaha mikro, kecil dan menengah Mitra Binaan Bank Sumut Cabang Medan dapat diterima. Hasil dari pada uji F sebagai berikut :

\section{Tabel 9}

ANOVA $^{\mathrm{a}}$

\begin{tabular}{|c|c|c|c|c|c|}
\hline Model & Sum of Squares & df & Mean Square & $\mathrm{F}$ & Sig. \\
\hline $\begin{array}{ll}1 & \text { Regression } \\
& \text { Residual } \\
& \text { Total }\end{array}$ & $\begin{array}{l}2,262 \\
9,797 \\
12,059\end{array}$ & $\begin{array}{l}2 \\
75 \\
77\end{array}$ & $\begin{array}{l}1,131 \\
, 265\end{array}$ & 4,271 &, $021^{\mathrm{b}}$ \\
\hline
\end{tabular}

a. Dependent Variable: Pengguna Informasi Akuntansi

b. Predictors: (Constant), Kepelatihan, Pendidikan.

Sumber : data diolah, 2018

Dari Tabel 9 di atas terdapat nilai signifikansi model regresi secara simultan sebesar 0,021 yang berarti nilai tersebut lebih kecil dari signifikansi level $0,05(5 \%)$ yaitu $0,001<0,05$ sedangkan diperoleh nilai $F_{\text {hitung }}$ sebesar 4,271 sedangkan $\mathrm{F}_{\text {tabel }}$ pada tingkat kepercayaan $95 \%(\alpha=0,05)$ adalah sebesar 2,68. 
Hal ini berarti bahwa nilai $F_{\text {hitung }}>F_{\text {tabel }}(5,782>2,68)$. Hal ini memberikan arti bahwa jenjang pendidikan pemilik, pelatihan akuntansi berpengaruh terhadap penggunaan informasi akuntansi pada usaha mikro, kecil dan menengah Mitra Binaan Bank Sumut Cabang Medan. Dengan demikian Ho3 ditolak sedangkan $\mathrm{H}_{\mathrm{a} 3}$ diterima. Sehingga dapat disimpulkan variabel jenjang pendidikan pemilik, pelatihan akuntansi, secara bersama-sama berpengaruh terhadap penggunaan informasi akuntansi pada usaha mikro, kecil dan menengah Mitra Binaan Bank Sumut Cabang Medan. Penelitian ini mendukung dari riset sebelumnya yang dilakukan oleh Grace (2003) dan Astuti (2007) bahwa faktor-faktor yang mempengaruhi penyediaan dan penggunaan informasi akuntansi pada UKM di antaranya pendidikan manajer/pemilik, skala usaha, umur usaha dan pelatihan akuntansi yang pernah diikuti manajer/pemilik.

Jenjang pendidikan akan sangat berpengaruh pada cara seseorang untuk berpikir, berperilaku dan bertindak. Jenjang pendidikan pemilik usaha akan mempengaruhi bagaimana pola pikirnya untuk mengelola dan mengganggap penting peranan informasi akuntansi untuk kelangsungan usahanya karena melalui informasi akuntansi yang didapat mereka akan dapat mengambil keputusan bisnis yang tepat karena informasi yang dihasilkan sifatnya akan lebih objektif dan dapat dipertanggungjawabkan kebenarannya.

Semakin banyak pelatihan akuntansi yang diperoleh maka hal ini akan membuat pelaku usaha merasa akan pentingnya penggunaan informasi akuntansi dalam menjalankan usahanya, karena penambahan pengetahuan tersebut akan membuka cakrawala berpikir tentang bagaimana mengelola usaha dengan benar berdasarkan catatan historikal setiap peristiwa ekonomi yang terjadi dalam entitas usaha.

\section{Uji Signifikan Parsial (Uji t)}

Pengujian ini bertujuan untuk mengetahui besarnya pengaruh masingmasing variabel independen secara individual (parsial) terhadap variabel dependen. Hasil dari uji t pada Tabel 10 berikut :

Tabel 10

Coefficients $^{\mathrm{a}}$

\begin{tabular}{|c|c|c|c|c|c|c|}
\hline \multirow[b]{2}{*}{ Model } & & \multicolumn{2}{|c|}{$\begin{array}{l}\text { Unstandardized } \\
\text { Coefficients }\end{array}$} & $\begin{array}{l}\text { Standardized } \\
\text { Coefficients } \\
\end{array}$ & \multirow[b]{2}{*}{$\mathrm{t}$} & \multirow[b]{2}{*}{ Sig. } \\
\hline & & $\mathrm{B}$ & $\begin{array}{l}\text { Std. } \\
\text { Error }\end{array}$ & Beta & & \\
\hline \multirow[t]{3}{*}{$\overline{1}$} & (Constant) & 0,516 & 1.088 & & 0,474 & .638 \\
\hline & Pendidikan & .131 & .157 & .125 & 1 & .407 \\
\hline & Kepelatihan & .566 & .198 & .427 & 2.867 & .007 \\
\hline
\end{tabular}

a. Dependent Variable: Pengguna Informasi Akuntansi

Sumber : data diolah, 2018

Berdasarkan tabel di atas menunjukkan bahwa hasil pengujian secara parsial adalah sebagai berikut:

a. Berdasarkan uji $\mathrm{t}$ diperoleh nilai $\mathrm{t}$ hitung variabel jenjang pendidikan adalah sebesar 0,838 sedangkan nilai $t$ tabel adalah 1,990 maka $(0,838<1,990)$ tidak 
berpengaruh signifikan terhadap penggunaan informasi akuntansi ( $t_{\text {hitung }}<$ $\left.t_{\text {tabel }}\right)$. Selain itu dapat juga dilihat dari nilai signifikansi variabel jenjang pendidikan sebesar $0,407>0,05$. Dengan demikian dapat disimpulkan menerima $\mathrm{H}_{01}$ dan menolak $\mathrm{H}_{\mathrm{a}} 1$ artinya secara parsial variabel jenjang pendidikan tidak berpengaruh signifikan terhadap penggunaan informasi akuntansi dimana nilai $t_{\text {hitung }}<\mathrm{t}_{\text {tabel }}$ dan nilai $\mathrm{p}$-value $0,075>0.05$. Hasil penelitian ini tidak sesuai dengan hasil penelitian yang dikemukakan oleh Astuti (2007) dan beberapa peneliti lainnya yang mengungkapkan bahwa terdapat pengaruh antara tingkat pendidikan manajer/pemilik terhadap penggunaan informasi akuntansi pada usaha kecil dan menengah.

Namun hasil penelitian ini sesuai dengan penelitian yang dilakukan Hariyadi (2013) yang mengungkapkan bahwa pendidikan tidak berpengaruh signifikan terhadap penggunaan informasi akuntansi pada usaha mikro, kecil dan menengah (UMKM) di Kota Tanjung Pinang. Penelitian ini menemukan bahwa walaupun pendidikan pemilik rendah tapi ternyata para pengusaha masih mempunyai inisiatif untuk menyediakan dan menggunakan informasi akuntansi dalam usahanya walaupun informasi yang disediakan masih tergolong sangat sederhana dan kurang sesuai dengan standar. Mereka mendapatkan informasi tentang akuntansi dari luar pendidikan formal seperti membaca buku dan mengikuti pelatihan-pelatihan akuntansi.

b. Berdasarkan uji t diperoleh nilai t hitung variabel kepelatihan adalah sebesar 2,867 sedangkan nilai t tabel adalah 1,990 maka (2,867>1,990) berpengaruh signifikan terhadap penggunaan informasi akuntansi $\left(t_{\text {hitung }}>t_{\text {tabel }}\right)$. Selain itu dapat juga dilihat dari nilai signifikansi variabel kepelatihan sebesar 0,007 < 0,05 . Dengan demikian dapat disimpulkan menerima $\mathrm{H}_{\mathrm{a} 2}$ dan menolak $\mathrm{H}_{02}$ artinya secara parsial variabel kepelatihan berpengaruh signifikan terhadap penggunaan informasi akuntansi dimana nilai $t_{\text {hitung }}>\mathrm{t}_{\text {tabel }}$ dan nilai $p$-value $0,007<0.05$.

Hasil ini sesuai dengan teori yang dikemukakan Holmes dan Nicholls (1989) dan hasil penelitian yang dilakukan Grace (2003) dan Astuti (2007), yang menemukan bahwa pelatihan akuntansi yang pernah diikuti manajer/pemilik usaha ternyata berpengaruh terhadap penyediaan dan penggunaan informasi akuntansi dalam usahanya. Pelatihan akuntansi yang dimaksud adalah pelatihan akuntansi yang diselenggarakan oleh suatu lembaga pendidikan luar sekolah, lembaga pendidikan tinggi dan balai pelatihan departemen atau dinas tertentu. Manajer/pemilik yang pernah mengikuti pelatihan akuntansi akan cenderung menyelenggarakan akuntansi bagi usahanya. Hal ini dikarenakan manajer/pemilik usaha telah menyadari pentingnya akuntansi dalam menjalankan usahanya.

\section{KESIMPULAN}

Berdasarkan pengujian yang telah dilakukan, maka dapat diperoleh kesimpulan sebagai berikut:

1. Secara simultan variabel jenjang pendidikan pemilik, pelatihan akuntansi berpengaruh terhadap penggunaan informasi akuntansi pada usaha mikro, kecil dan menengah mitra binaan Bank Sumut Cabang Medan dapat diterima. Hasil penelitian ini memperkuat penelitian Grace (2003) dan Astuti (2007).

2. Secara parsial, jenjang pendidikan, tidak berpengaruh signifikan terhadap penggunaan informasi akuntansi pada UMKM. Hasil penelitian ini 
memperkuat penelitian yang dilakukan Hariyadi (2013). Sedangkan kepelatihan akuntansi berpengaruh signifikan terhadap penggunaan informasi akuntansi pada UMKM. Hasil penelitian ini sejalan dengan hasil penelitian yang dilakukan Grace (2003) dan Astuti (2007), yang menemukan bahwa pelatihan akuntansi yang pernah diikuti manajer/pemilik usaha ternyata berpengaruh terhadap penyediaan dan penggunaan informasi akuntansi dalam usahanya.

\section{DAFTAR PUSTAKA}

[1] Amrin, Abdullah. 2009. Bisnis, Ekonomi, Asuransi, dan Keuangan Syariah. Jakarta: Gramedia Widiasarana Indonesia (Grasindo).

[2] Andi, M.K . 2009. Analisis Usaha Kecil dan Menengah. Andi, Yogyakarta: Yogyakarta.

[3] Arikunto, Suharsimi, 2006. Prosedur Penelitian Suatu Pendekatan Praktik. Jakarta: Rineka Cipta.

[4] Astuti, 2007. Pengaruh Karakteristik Internal Perusahaan Terhadap Penyiapan dan Penggunaan Informasi Akuntansi Perusahaan Kecil dan Menengah di Kabupaten Kudus. Thesis dipublikasikan. UNDIP.

[5] Baridwan, 2004. Intermediate Accounting, Edisi Kedelapan. Yogyakarta: BPFE.

[6] Baas dan Schrooten, 2006. Banking and SMEs :A Theoretical Analysis Small Economic.

[7] Belkaoui, A.R., 2011. Accounting Theory. Fourth Edition, Business Press, Thomson.

[8] Ediraras, 2010. Akuntansi dan Kinerja UMKM. Jurnal Ekonomi Bisnis No.2 Vol. 15.

[9] Ghozali, Imam. 2006. Aplikasi Analisis Multivariate Dengan Program SPSS. Cetakan keempat. Universitas Diponegoro.

[10] Grace, Tianna, Solovida, 2003. Analisis Faktor- Faktor Mempengaruhi Penyiapan Dan Penggunaan Informasi Akuntansi Pada Perusahaan Kecil Dan Menengah Di Jawa Tengah. Universitas Diponegoro.

[11] Hadiyah, Fitriyah, 2006. Analisis Faktor-Faktor yang Mempengaruhi Penggunaan Informasi Akuntansi pada Usaha Kecil dan Menengah. Tesis Magister. Universitas Negeri Jakarta.

[12] Handayani, 2011. Faktor-Faktor yang Mempengaruhi Penggunaan Informasi Akuntansi Usaha Kecil dan Menengah. Jurnal akuntansi. UNES Semarang.

[13] Holmes, Scoott and Des Nicholls. 1989. Modelling The Accounting Information Requirement of Small Business. Accounting and Business Research, Vol. 19, no 74, pp. 143-150, 1989.

[14] Kemenkop UMKM, Undang-Undang Republik Indonesia No.20 Tahun 2008 tentang Usaha Mikro, Kecil dan Menengah.

[15] Media Bisnis UKM, 2014. Perkembangan UMKM Di Indonesia. Online). (http:// http://pacitandeal.com/perkembangan-umkm-di-indonesia/), (diakses 29 Nopember 2017).

[16] Mulyadi, 2001. Sistem Akuntansi. Edisi Ketiga. Yogyakarta : Salemba Empat.

[17] Nisa, K. 2011. Strategi Pemasaran Untuk Usaha Kecil Menengah. (Online). (http://consumerbehavior.lecture.ub.ac.id/2011/12/strategi-pemasaranuntuk-usaha-kecil-menengah/), (diakses 19 Desember 2017). 
[18] Rudiantoro, 2012. Kualitas Laporan Keuangan Usaha Mikro Kecil dan Menengah serta Prospek Implementasi SAK ETAP ,Universitas Indonesia .Jurnal Akuntansi dan Keuangan Indonesia, Volume 9- No1.

[19] Salamah, L., 2010. Lingkaran Krisis Ekonomi Indonesia. Jurnal Masyarakat Kebudayaan dan Politik. Volume 14, Nomor 2: 65-76.

[20] Samuj, H. R., 2007. IFRS for SMEs: A New Zealand Perspective. International Small Business Jounal, 19 (2).

[21] Sekaran, Uma, 2009. Research Methods for Business. Salemba empat.

[22] Singarimbun, Masri dan Sofyan, Effendi, 1995. Metode Penelitian Survei. PT Pustaka LP3ES. Jakarta.

[23] Sugiono, Arief dan Untung Edy, 2008. Panduan Praktis Dasar Analisa Laporan Keuangan. Jakarta: Gramedia Widiasarana Indonesia (Grasindo).

[24] Suryo, Anak, 2008, Akuntansi untuk UMKM, Metode Akuntansi Praktis dan Sederhana untuk UMKM. Media Pressindo: Yogyakarta.

[25] Susanto, 2008. Sistem Informasi Akuntansi. Linggajaya: Bandung.

[26] Wahyudi, 2009. Analisis Faktor-Faktor yang Mempengaruhi Penggunaan Informasi Akuntansi pada Usaha Kecil dan Menengah di Yogyakarta. Thesis. UNDIP Semarang. 